\title{
THE CORRELATION BETWEEN DEMAND FACTORS AND HEALTH CARE SERVICE UTILIZATION BY CONTRIBUTION BENEFICIARY PATIENTS
}

\author{
Hubungan Faktor-Faktor Permintaan dan Pemanfaatan Pelayanan Kesehatan oleh \\ Pasien Penerima Bantuan Iuran
}

\author{
Leli Rachmawati ${ }^{1}$, ${ }^{\text {Isma Faridatus Sholihah }}{ }^{2}$ \\ ${ }^{1}$ Field Epidemiology Training Program, Universitas Gadjah Mada, Indonesia \\ ${ }^{2}$ The Indonesian Public Health Association of Surabaya, Indonesia \\ ${ }^{*}$ Correspondence: isma.faridatus.olihah-2015@fkm.unair.ac.id
}

\begin{abstract}
Background: National Health Insurance is the government's effort to increase public access to health care services. As the implementer of the National Health Insurance, the Outpatient Unit of Haji General Hospital, Surabaya has undergone the decrease of contribution beneficiaries' visits from 2010-2013. This condition indicates a decrease in health care utilization by the low-income community.

Aim: This study aims to identify the correlation between health care demands and health care utilization by the contribution beneficiary patients.

Method: The study was an observational analytic using a cross-sectional design. A systematic random sampling technique was used to determine the sample of the study. The respondents were 74 contribution beneficiary patients who possessed a district government free care scheme and had ever utilized the health care services at the Outpatient Unit of Haji General Hospital, Surabaya, and at least 13 years old. The data were collected through questionnaires and analyzed with Spearman and Chi-Square tests $(\alpha=0.05)$.

Results: Health status, insurance needs, additional costs, gender, ethnicity, education, and income did not have a significant correlation with the health care service utilization by the contribution beneficiary patients at the Outpatient Unit of Haji General Hospital. It was identified that the older the people are, the higher the frequency of health care utilization is. Besides, service time was proven to be the determinants of health care utilization ( $p$ $=0.006$ ).

Conclusion: The most influential factors in utilizing the health care services by contribution beneficiary patients are service time and age. Based on those factors, the Haji General Hospital requires to improve its services and service timeliness for the elderly contribution beneficiary patients.
\end{abstract}

Keywords: demand, contribution beneficiary patients, utilization.

\section{ABSTRAK}

Latar Belakang: Jaminan Kesehatan Nasional merupakan upaya pemerintah untuk meningkatkan akses masyarakat ke pelayanan kesehatan. Sebagai pelaksana Jaminan Kesehatan Nasional, Unit Rawat Jalan di RSU Haji, Surabaya mengalami penurunan kunjungan Pasien Penerima Bantuan luran (PBI) dari 2010-2013. Hal ini mengindikasikan menurunnya pemanfaatan fasilias kesehatan oleh masayarakat miskin.

Tujuan: Penelitian ini mengidentifikasi hubungan demand pelayanan kesehatan dan pemanfaatan pelayanan kesehatan pada pasien PBI.

Metode: Penelitian dilakukan dengan desain penelitian observasional analitik dan cross sectional. Teknik pengambilan sampel dilakukan dengan metode systematic random sampling. Responden adalah 74 Pasien PBI yang memiliki kartu Jamkesmas dan pernah memanfaatkan pelayanan di Unit Rawat Jalan Rumah Sakit Umum Haji, Surabaya, serta berusia minimal 13 tahun. Pengambilan data dilakukan menggunakan instrumen berupa kuisioner dan pengujian hubungan dianalisis menggunakan uji korelasi Spearman dan Chi Square $(\alpha=0,05)$.

Hasil: Status kesehatan, kebutuhan keamanan, biaya tambahan, jenis kelamin, etnis, pendidikan, dan pendapatan tidak memiliki hubungan yang signifikan dengan pemanfaatan layanan kesehatan untuk pasien PBI di Instalasi Rawat Jalan Rumah Sakit Umum Haji Surabaya. Diketahui pula, semakin tua seseorang, maka semakin tinggi frekuensi pemanfaatan layanan kesehatan. Juga, waktu layanan menentukan pemanfaatan layanan kesehatan $(p=0,006)$.

Kesimpulan: Faktor yang paling menentukan pemanfaatan pelayanan kesehatan adalah waktu pelayanan dan usia. Berdasarkan alasan tersebut, Rumah Sakit Umum Haji Surabaya harus meningkatkan pelayanan pada kelompok usia lanjut pada Pasien PBI dan juga ketepatan waktu pelayanan.

Kata kunci: demand, pasien penerima bantuan iuran, pemanfaatan. 


\section{INTRODUCTION}

The utilization of health care service is highly essential for the community to maintain, improve, prevent, and cure diseases, as well as restore the health of individuals and families. Several medical services and public health care services are health promotion, environmental health care, maternal, and child health care/family planning, nutrition improvement efforts as well as communicable diseases eradication and treatment (Sampeluna, Balqis, and Asiah Hamzah, 2013).

Health greatly affects the personal quality of life. Health is one of the main capitals for individuals to carry out their daily activities. To improve individuals' health status, it requires health care efforts. One of the efforts is the establishment of health care facilities to maintain and handle various health problems. Unfortunately, not everyone who needs health care services can access health care services. This inability may due to internal or external barriers.

One of the government's efforts to improve access to high-quality health care services is by establishing a health insurance program. The health service improvement is intended for all Indonesians. For those who have difficulty in accessing health care services due to costs, the Regulation Number 44 of 2004 concerning the National Social Insurance System Article 17 Paragraph 4 stated that the government grants beneficiaries for the low-income community. Thus, the low-income community who become the contribution beneficiaries could access health care services for free because the government has granted a district government free care scheme.

Haji General Hospital under the East Java Government organizes health care services for both health insurance participants and the general public. In accordance with the Decree of the Indonesian Ministry of Health Number 1003/Menkes/SK/X/2008, Haji General Hospital has changed its status to a Type B Teaching Hospital. The services provided at Haji General Hospital include the emergency room, outpatient care, inpatient care, intensive care unit (ICU), surgical center, and other services that support the performance of the hospital. Based on the annual report of the Surabaya City Health Office, the total referrals proposed at the Haji General Hospital in 2010 reached 14,095 patients. This number decreased to 11,534 referrals in 2011. From 2010 to 2011, the number of visits done by patients with a district government free care scheme decreased by $18.17 \%$. Meanwhile, based on the annual report of Haji General Hospital, there was a decrease in contribution beneficiary visits at the outpatient unit of Haji General Hospital during the period of $2010-2013$ amounted to $17.89 \%$. The decrease of contribution beneficiary visits becomes an indicator of the lack of health care service utilization by the low-income community.

One of the factors determining health care services utilization is access to health care services. Various factors influence the access level to health care services, one of which is the demand for health care services. The Law of Demand according to Alfred Marshal stated "when the price of an item rises, the demand for the item will decrease.
Conversely, if the price of the item falls, the demand will rise with the assumption of all other things being equal (all factors that influence demand, except prices, are considered constant)" (Folland, Goodman, and Stano, 2013). The health insurance program is useful for increasing the access of people to fulfill their needs for quality health services. The fluctuation of the health care service cost will not become an obstacle in demand for health care services and for those who have become contribution beneficiaries. It becomes a reason for further research to investigate other demand factors and their correlation with the health care service utilization by contribution beneficiaries.

This study aims to determine the correlation between demand factors and health care service utilization at the Outpatient Unit of Haji General Hospital. The demand factors consist of health status, coinsurance, rates, income, age, gender, ethnicity, education, and service time. The results of this study are expected to be used for the evaluation and planning of health care services at the Outpatient Unit of Haji General Hospital.

\section{METHOD}

This study was an analytic observational with cross-sectional design to determine the correlation between demand factors and the health care service utilization by contribution beneficiary patients. This research was conducted by distributing questionnaires to patients who utilized health care services at the Outpatient Unit of Haji General Hospital, Surabaya in May-June 2014.

The population of this study was all of the contribution beneficiaries with a district government free care scheme who utilized the services at the Outpatient Unit of Haji General Hospital. The sampling technique used was a systematic random sampling method, and 74 people were taken as respondents. The patients studied were contribution beneficiaries with a district government free care scheme who had utilized the services at the Outpatient Unit of Haji General Hospital and were at least 13 years old. The descriptive analysis was presented in a frequency distribution table, while the correlation was analyzed using Spearman and ChiSquare correlation tests. The supporting data were the number of Haji General Hospital visits.

This study grouped the health status into two categories, i.e., low and high frequency of illness. The low frequency of illness was a group of respondents who had suffered from an illness less than three times, while the high frequency of illness was for those who were ill for more than three times. The coinsurance variable or health insurance needs are divided into low insurance needs and high insurance needs. This health insurance needs could be observed from the health care service utilization accessed by people who were not health insurance participants. For those who were not health insurance participants, but they were able to utilize health care services that were grouped into the low insurance need group. Conversely, for those who were not able to utilize health care services included 
in the high insurance need group. In this research, the contribution beneficiary patients at Haji General Hospital were divided into 4 groups consisting a group for those with income less than IDR 200,000, a group for those with income ranging from IDR 200,000-IDR 750,000, a group for those with income ranging from IDR 751,000 -IDR $1,500,000$ and a group for those with income more than IDR $1,500,000$. Service time is the minimum time used to serve a patient starting from the registration process until returning home. In this study, the researchers grouped the time length into four groups: very long, long, short, and very short.

Table 1. The Correlation between Demand Factors and Health Care Service Utilization by Contribution Beneficiary Patients at the Outpatient Unit of Haji General Hospital.

\begin{tabular}{|c|c|c|c|c|c|}
\hline \multirow{3}{*}{ Demand Factors } & \multicolumn{4}{|c|}{ Utilization } & \multirow{3}{*}{ p-value } \\
\hline & \multicolumn{2}{|c|}{ Low } & \multicolumn{2}{|c|}{ High } & \\
\hline & $\mathbf{n}$ & $\%$ & $\mathbf{n}$ & $\%$ & \\
\hline \multicolumn{6}{|l|}{ Health Status } \\
\hline Low Frequency of Illness ( $\leq 3$ times) & 24 & 49 & 25 & 51 & \multirow[t]{2}{*}{0.621} \\
\hline High Frequency of Illness (> 3 times) & 7 & 28 & 18 & 72 & \\
\hline Coinsurance & & & & & 0.583 \\
\hline Low & 15 & 45.5 & 18 & 54.5 & \\
\hline High & 16 & 39 & 25 & 61 & \\
\hline \multicolumn{6}{|l|}{ Surcharge } \\
\hline Added & 2 & 15.4 & 11 & 86.4 & \multirow[t]{2}{*}{0.068} \\
\hline Unadded & 29 & 47.5 & 32 & 52.5 & \\
\hline \multicolumn{6}{|l|}{ Age } \\
\hline Teen (13-25 years old) & 4 & 80 & 1 & 20 & \multirow{4}{*}{0.003} \\
\hline Adult (26-45 years old) & 9 & 52.9 & 8 & 47.1 & \\
\hline Middle-Aged (46-65 years old) & 18 & 36.7 & 31 & 63.3 & \\
\hline Elderly (>65 years old) & 0 & 0 & 3 & 100 & \\
\hline \multicolumn{6}{|l|}{ Gender } \\
\hline Men & 10 & 40 & 15 & 60 & \multirow[t]{2}{*}{1} \\
\hline Women & 21 & 42.9 & 28 & 57.1 & \\
\hline \multicolumn{6}{|l|}{ Ethnicity } \\
\hline Javanese & 27 & 39.1 & 42 & 60.9 & \multirow[t]{2}{*}{0.154} \\
\hline Madurese & 4 & 80 & 1 & 20 & \\
\hline \multicolumn{6}{|l|}{ Education Level } \\
\hline Not graduated from Elementary School & 2 & 18.2 & 9 & 81.8 & \multirow{5}{*}{0.109} \\
\hline Elementary School Graduate & 13 & 39.4 & 20 & 60.6 & \\
\hline Junior High School Graduate & 11 & 61.6 & 7 & 38.9 & \\
\hline High School Graduate & 5 & 45.5 & 6 & 54.4 & \\
\hline College Graduate & 0 & 0 & 1 & 100 & \\
\hline \multicolumn{6}{|l|}{ Income } \\
\hline$<$ IDR 200,000,00 & 1 & 100 & 0 & 0 & \multirow{4}{*}{0.554} \\
\hline IDR $200,000,00-$ IDR $750,000,00$ & 9 & 40.9 & 13 & 59.1 & \\
\hline IDR $751,000,00-$ IDR $1,500,000,00$ & 17 & 47.2 & 19 & 52.8 & \\
\hline > IDR1,500,000,00 & 4 & 26.7 & 11 & 73.3 & \\
\hline \multicolumn{6}{|l|}{ Service Time } \\
\hline Very Long & 4 & 22.2 & 14 & 77.8 & \multirow{4}{*}{0.006} \\
\hline Long & 7 & 36.8 & 12 & 63.2 & \\
\hline Short & 9 & 50 & 9 & 50 & \\
\hline Very Short & 11 & 57.9 & 8 & 42.1 & \\
\hline
\end{tabular}

\section{RESULTS AND DISCUSSION}

\section{The Demand for Health Care Services}

Demand for health and demand for health care services are two different aspects. Demand for health is a demand for a health condition. On the other hand, the demand for health care services is a demand for a healthy condition as proven with treatment by medical personnel. Health care services are the input of the process of making health conditions. Therefore, the demand for health care services, such as hospitals, depends on the health demand itself. Within the scope of health, demand can be defined as goods or services that are purchased by patients. Doctors' recommendations or other factors can influence demand.

The study involved 74 respondents, and the majority of them were women $(66,2 \%)$ in the age range of 46-65 and had a public health insurance card. The results indicated that there was a correlation between demand factors and health care service utilization by contribution beneficiary patients 
at the Outpatient Unit of the Haji General Hospital. The demand for health care services, according to Folland, Goodman, and Stano (2013), is determined by health status, coinsurance (collateral needs), cost (surcharge), age, gender, ethnicity, education level, income, and time.

\section{The Correlation between Health Status and Health Care Service Utilization}

The first factor that influences the demand for health care services is health status. Health status is an influential factor in increasing health care service utilization. A person with a low health status will cause an increase in health care service utilization which may be in the form of visiting doctors, clinics, primary healthcare centers, and hospitals. According to HL Blum (1981), an individual's health status is influenced by several factors, i.e., heredity, environment, behavior, and health care services. The availability of high-quality health care facilities can accelerate the improvement of public health. In addition, health care facilities must also be equipped with accessibility to all levels of society.

Through the National Health Insurance program, the government has sought to improve access to quality health care services for all Indonesians. Through the National Health Insurance program, it is expected that the public can efficiently utilize quality health care services according to their needs. Furthermore, the low-income community has also been granted as beneficiaries by the government. Hence, they can access health care services like other people without worrying about the medical cost that must be paid.

The result of this study suggested that the respondents with a low frequency of illness had lower utilization than those who had a high frequency of illness. Moreover, the result of statistical tests indicated that there was no significant correlation between health status and health care service utilization at the Outpatient Unit of Haji General Hospital with $p$-value of0.621. This result was contrary to the result of recent research conducted by Rohmah (2017), which stated that, statistically, health status had a significant correlation to the regular health care service utilization. The excellent health status would reduce the regular service utilization.

\section{The Correlation between Health Insurance Needs and Health Care Service Utilization}

Insurance ownership significantly affects health care services utilized by an individual. Health insurance participants can easily access health care services. Thus, health care service utilization will also increase. During the implementation of National Health Insurance, the patient visits to utilize health care services in hospitals, which is referred to as Referral Health care Facilities or Fasilitas Kesehatan Tingkat Lanjut (FKTL), are strongly influenced by the referral system. The practical guide of the Social Security Agency for Health (BPJS Kesehatan) explains that the health care service referral system is a regulation on the provision of health care services that regulates the transfer of duties and responsibilities for reciprocal health care, both vertically and horizontally. In addition, it must be carried out by health insurance participants and all health care facilities. Contribution beneficiaries who need access to health care facilities are highly dependent on the referral system, both vertical and horizontal referrals from Primary Care Facilities.

As many as $54.5 \%$ of the people in the low coinsurance category had high utilization of health care services. This number was lower compared to the high coinsurance category, which had health care services utilization amounting to $61 \%$. After identifying the frequency of health care service utilization in each group, the Spearman correlation test obtained $p$-value of 0.583 . Hence, it could be concluded that coinsurance or health insurance needs did not have a significant correlation with health care service utilization.

\section{The Correlation between Additional Costs and Health Care Service Utilization}

Based on the President Regulation of Indonesian Number 19 of 2016, the benefits package is provided by the National Health Insurance Program to fulfill the patient's medical needs. It should be applied to all members of health insurance, both contribution beneficiaries, and non-contribution beneficiaries. Contribution beneficiary patients will not be reimbursed for medical services except in certain conditions. Through this study at the Outpatient Unit of Haji General Hospital, the researchers identified that health facilities might incur additional costs to the contribution beneficiary patients when they trespass the applicable procedures and provisions. This case might occur when the contribution beneficiary patients disobeyed the referral system rules and directly visited the hospital without a referral from the primary care facilities where they were registered. In addition, contribution beneficiary patients could also be charged with additional costs if they asked for other treatments that were not subject to their treatment classes, or instances, asking for additional vitamin supplements and medications, and medical actions that were not medically necessary.

Based on the result of this research, there were $86.4 \%$ of the contribution beneficiary patients who had to pay additional costs due to the additional utilization of health care services, while the rest, $52.5 \%$ of them, were charged with no additional costs. Through the additional cost for contribution beneficiaries, it provided public understanding about their rights and obligations on their Primary Level Care and Referral Health care Facilities of the National Health Insurance program. A significant $p$ value of 0.068 with $(\alpha=5 \%)$ was obtained from the Chi-square test. It could be concluded that the health care service utilization by contribution beneficiary patients was not significantly related to the additional costs that might be paid by the contribution beneficiary patients. 
The Correlation between Age and Health Care Service Utilization

According to Folland, Goodman, and Stano (2013), age affects health care service utilization since different age levels have different risks of illness. Therefore, age becomes an important variable in health care service utilization. This statement is in line with the study conducted by Londo, Tucunan, and Maramis (2017) which stated that there is a correlation between the age of patients and service utilization. Children and the elderly group are usually susceptible to diseases and highly utilize health care services.

The respondents of this study were divided into 4 groups based on their ages from the Ministry of Health, including teenager group aged 13-25 years, the adult group aged $26-45$ years, the middleaged group aged $46-65$ years, and the elderly group aged over 65 years. Table 1 indicated the majority of health service utilization was classified as low utilization for the teenager group (13-25 years) which reached $80 \%$, while the highest utilization was reached by the elderly group or $>65$ years old with $100 \%$. Meanwhile, the second-highest utilization reached by the middle-aged group with $63.3 \%$. The Spearmen Test obtained p-value of 0.003 which indicated that age had a significant correlation with the health care service utilization by health insurance patients/contribution beneficiary patients. The older a person is, the higher his health care service utilization will be. This matter occurs because the middle-aged and elderly people have a high risk of disease due to the decrease of their body function.

\section{The Correlation between Gender and Health Care Service Utilization}

The need for health care services can be influenced by gender. The physiological condition becomes one of the factors that affect men and women to hold different health needs. It can be perceived by the number of contributions beneficiaries of this study. There were 25 men $(33.78 \%)$, while there were 49 women $(66.2 \%)$. This result was in accordance with the study conducted by Tasya, Andriany, and Herwanda (2016) which explained that the characteristics of patients that affect the health care service utilization are gender. It found that women utilize health care services more than men.

A Chi-Square test was conducted to identify the correlation between gender and health care service utilization. P-value of 1 indicated that there was no significant correlation between gender and health care service utilization. The p-value of 1 indicated that the health care service utilization for men and women was equal.

This result was contrary to the study conducted by Weeratunga and Dissanayake (2017) which stated that for an adult women group, expenditure on drugs had been the most significant factor which influenced the demand for health care services as same as in the case of adult men group.
Treatment method, health status, and cost per visit for medical treatment could be regarded as the major determinants of health care demand for elderly women. Amongst all, the medical treatment method of elderly women had a stronger correlation with a number of visits for medical consultations (demand for health care). Elderly patients who suffered from non-communicable diseases received medical treatments for a long period of time. However, Łyszczarz (2017) stated that Polish medical care suffered from gender bias, which possibly made men more responsive to medical care. The mean reimbursement per service for men was higher in most medical care areas; men reported that fewer problems with access to health care, and their mortality trend exhibited more favorable evolution over time.

\section{The Correlation between Ethnicity and Health Care Service Utilization}

Ethnicity is related to a social group in cultural systems that have a certain meaning or position because of its descents, customs, religions, languages, and so forth. Indonesia is a country with several ethnicities and cultures. Each ethnicity has cultures and habits that are different from others, including its perception of health. Most of the visitors of Haji General Hospital were from Javanese and Madurese ethnic groups. Based on the result of this study, the majority of Javanese ethnicity amounted to $60.9 \%$ and had higher health care service utilization compared to Madurese with health care service utilization reached $80 \%$. The result of this frequency distribution indicated that ethnic characteristics correlated with health care service utilization.

Chi-Square statistical test was performed and, $p$-value of 0.154 was obtained to prove this correlation. It could be concluded that ethnicity did not hold a significant correlation with health care service utilization.

\section{The Correlation between Education and Health Care Service Utilization}

Educational background is an aspect that influences the individual level of knowledge about several fields. Based on the study of KAP (Knowledge, Attitude, and Practice), knowledge can affect a personal attitude or behavior in carrying out certain actions such as health care service utilization. Hence, the education variable might be related to health care service utilization by contribution beneficiary patients. Based on research conducted by Napirah, Rahman and Tony (2016), it was proven that there was a correlation between family education and health care service utilization. A research conducted by Wardana (2017) also stated that there was a significant correlation between the education level of participants and health care service utilization in Rowosari Primary Healthcare Center.

In this study, the researchers categorized the education level of respondents into several groups, i.e., no degree, elementary school graduate, junior 
high school graduate, high school graduate, and university graduate. The frequency distribution result indicated that, on average, the respondents had a high health care service utilization at all education levels, except in the high school graduate group. The majority of respondents who graduated from junior high school with $61.5 \%$, had a low health care service utilization. A Spearman test obtained $p$-value of 0.109 $(\alpha=0.05)$, it suggested that education had no significant correlation with health care service utilization by contribution beneficiary patients at the Outpatient Unit of Haji General Hospital. The research conducted by Ulfa, Kuswardinah, and Mukarromah (2017) also stated that there is no significant correlation between education level and knowledge with health care service utilization.

\section{The Correlation between Income and Health Care Service Utilization}

Income becomes a crucial variable in health care service utilization. A study conducted by Syarifain, Rumayar, and Mandagi (2017) stated that there was a non-linear correlation between income and health care service utilization. It indicated that the higher the income, the lower health care service utilization would be. This argument was supported by studies conducted by Napirah, Rahman and Tony (2016) and Putra (2010) which explained that there was a correlation between family income and health care service utilization, but the researchers did not elaborate more about the type of correlation. The access to health care services was sometimes hindered by inadequate financial and material resources which were characterized by poverty and material deprivation that built a barrier for the public to access health care services (Ursulica, 2016).

The result indicated that the majority of respondents had an income ranging from IDR 751,000 -IDR 1,500,000, and only one respondent with the lowest income of less than IDR 200,000. According to Table 1, the highest health care service utilization was reached by respondents with income more than IDR 1,500,000-IDR 2,200,000 amounted to $73.3 \%$. Meanwhile, the lowest health care service utilization was group with income less than IDR 200,000 amounted to $100 \%$. To identify the correlation between income and health care service utilization, the Spearman correlation test was conducted and obtained a p-value of 0.554 . Hence, it could be concluded that there was no significant correlation between income and health care service utilization by contribution beneficiary patients at the Outpatient Unit of Haji General Hospital.

\section{The Correlation between Service Time and Health Care Service Utilization}

The time spent to access health care services is one of the factors that determine the demand for health care services (Folland, Goodman, and Stano, 2013). Time is a significant variable in health care services since fast and appropriate services are one of the public expectations in utilizing health care services (Laeliyah and Subekti, 2017). The time that must be spent by the public to access health care services can also affect public satisfaction. Service time is the minimum time spent to serve a patient from the registration process until returning home. In accordance with the Decree of Indonesian Ministry of Health Number 129 of 2008, the standard service time is approximately 90 minutes with the distribution of service consisting of waiting time $\leq 60$ minutes, doctor examination time $\geq 15$ minutes, and a minimum of 15 minutes for administration and taking drugs. Accordingly, the service time at the hospital will indirectly affect the length of time for a patient to receive health care services.

In this study, the researchers grouped the service time length into four groups: very long, long, short, and very short service time. Reviewing from the proportion of respondents' answers, it was identified that most of the respondents who had low health care services utilization, amounting to $57.9 \%$, were taking a short time in utilizing health care services. Conversely, the majority of respondents who had high utilization of health care services, reaching to $77.8 \%$, were taking a very long time in utilizing health care services. Hence, the lower health care service utilization was, the shorter service time the patient might spend and vice versa. Based on the Spearman test, it obtained p-value of0.006, and it indicated that service time spent by contribution beneficiary patients had a significant correlation with health care service utilization.

\section{CONCLUSION}

Health status, insurance needs, additional costs, gender, ethnicity, education, and income have no significant correlation with the health care service utilization by contribution beneficiary patients at the Outpatient Unit of Haji General Hospital. However, age and service time variables are proven to be the determinants of health care service utilization. Based on these results, Haji General Hospital needs to improve its services for the middle-aged and elderly people, and the timeliness of its services, especially for the contribution beneficiary patients.

\section{CONFLICT OF INTEREST}

The authors state that there is no conflict of interest in this article.

\section{REFERENCES}

Folland, S., Goodman, A. C. and Stano, M. (2013) The Economics of Health and Health Care. 7th edn. New Jersey: Prentice Hall.

Laeliyah, N. and Subekti, H. (2017) 'Waktu Tunggu Pelayanan Rawat Jalan dengan Kepuasan Pasien Terhadap Pelayanan di Rawat Jalan RSUD Kabupaten Indramayu', Jurnal Kesehatan Vokasional, 1(2), pp. 102-112.

Londo, J. P., Tucunan, A. A. T. and Maramis, F. R. R. (2017) 'Hubungan antara Karakteristik Peserta BPJS Kesehatan dengan 
Pemanfaatan Pelayanan Puskesmas di Wilayah Kerja Puskesmas Tahuna Barat', Jurnal Kesehatan Masyarakat, 6(3), pp. 1-7.

Łyszczarz, B. (2017) 'Gender Bias and Sex-Based Differences in Health Care Efficiency in Polish Regions', International Journal for Equity in Health, 16(1), pp. 1-13. doi: 10.1186/s12939016-0501-y.

Napirah, M. R., Rahman, A. and Tony, A. (2016) 'Faktor-Faktor yang Berhubungan dengan Pemanfaatan Pelayanan Kesehatan di Wilayah Kerja Puskesmas Tambarana Kecamatan Poso Pesisir Utara Kabupaten Poso', Jurnal Pengembangan Kota, 4(1), pp. 29-39. doi: 10.14710/jpk.4.1.29-39.

Putra, A. W. (2010) Analisis Permintaan Penggunaan Layanan Kesehatan pada Rumah Sakit Umum Milik Pemerintah di Kabupaten Semarang. Undergraduate Thesis. Universitas Diponegoro.

Rohmah, F. N. (2017) 'Status Kesehatan dan Keteraturan Pemanfaatan Layanan Infertilitas', Jurnal Kebidanan, 6(1), pp. 5662.

Sampeluna, Balqis, N. and Hamzah, A. (2013) 'Faktor yang Berhubungan dengan Pemanfaatan Pelayanan Kesehatan di RSUD Lakipadada Kabupaten Tana Toraja', Jurnal Administrasi dan Kebijakan Kesehatan, 2(3), pp. 22-28.

Syarifain, A., Rumayar, A. A. and Mandagi, C. K. F. (2017) 'Hubungan antara Pendidikan dan Pendapatan dengan Pemanfaatan Pelayanan Kesehatan oleh Pasien BPJS di Wilayah Kerja Puskesmas Sario Kota Manado', Jurnal Kesehatan Masyarakat, 6(4), pp. 524-531.

Tasya, N., Andriany, P. and Herwanda (2016) 'Faktor-Faktor yang Berhubungan dengan Pemanfaatan Pelayanan Kesehatan Gigi dan Mulut di Rumah Sakit Gigi dan Mulut (RSGM) Universitas Syiah Kuala Banda Aceh', Journal Caninus Dentistry, 1(4), pp. 54-62.

Ulfa, Z. D., Kuswardinah, A. and Mukarromah, S. B. (2017) 'Faktor-Faktor yang Mempengaruhi Pemanfaatan Pelayanan Kesehatan Maternal Secara Berkelanjutan', Public Health Perspective Journal, 2(2), pp. 184-190.

Ursulica, T. E. (2016) 'The Relationship between Health Care Needs and Accessibility to Health Care Services in Botosani County- Romania', in International Conference - Environment at A Crossroads: SMART Approaches for A Sustainable Future. Bucharest: Procedia Environmental Sciences, pp. 300-310. doi: 10.1016/j.proenv.2016.03.035.

Wardana, B. K. and Suharto (2017) 'Hubungan Pendidikan dan Pengetahuan Peserta BPJS di Kelurahan Rowosari dengan Pemanfaatan Pelayanan Kesehatan di Puskesmas Rowosari', Jurnal Kedokteran Diponegoro, 6(1), pp. 46-53.

Weeratunga, L. and Dissanayake, L. (2017) 'Factors Influencing Demand for Health care Services Among The Elderly Women In Sri Lanka', International Journal of Advanced Research and Review, 2(4), pp. 35-47. 